\title{
Solar Light Induced Photo Catalytic Disinfection of Gram Positive and Negative Microorganisms from Water with Highly Efficient $\mathrm{AuTiO}_{2}$ Nanoparticle
}

Sandhya $\mathbf{S}^{1 *}$, Sadhana Rayalu ${ }^{2}$ and Benedict Bruno ${ }^{1}$

${ }^{1}$ CSIR-National Environmental Engineering Research Institute, CSIR-Complex, Chennai, India

${ }^{2}$ CSIR-National Environmental Engineering Research Institute, Nagpur, India

\begin{abstract}
$\mathrm{AuTiO}_{2}$ nanomaterial was used for solar photocatalytic disinfection of gram negative Escherichia coli and gram positive Staphylococci aureus. In this study, time of disinfection, light intensity, concentration of nanomaterial and bacterial concentration effects has been investigated. Prepared nanomaterial characterized using Scanning Electron Microscopy (SEM), X-Ray Diffractometry (XRD). AuTiO ${ }_{2}$ samples have shown antibacterial effect when irradiated in solar light. The bactericidal effect may be due to $\mathrm{Au}$ ions and photocatalysis of $\mathrm{TiO}_{2}$. The photocatalytic inactivation rate constant, $\mathrm{k}$ for each dose were obtained from their respective inactivation curve over a 2 hours incubation period.
\end{abstract}

Keywords: $\mathrm{AuTiO}_{2}$; Disinfection; E. coli; S. aureus; Solar; Photocatalyst; Antibacterial

\section{Introduction}

Contaminated water causes an estimated 6 to 60 billion cases of gastrointestinal illness annually and the majority of them are from rural areas of developing countries [1]. This is due to intermittent water supply, and water is polluted with variety of microorganisms. There is an urgent need of low cost, low maintenance and effective mode of disinfection for portable water. A safe affordable, robust and sustainable method for water purification is in great demand throughout the world [2]. Water disinfection means the removal, deactivation or killing of pathogenic microorganism including gram positive and negative bacteria, virus, fungi etc. Microorganisms are destroyed or deactivated, resulting in termination of growth and reproduction. Conventional method of water disinfection is by strong oxidant such as free chlorine [3] or UV/chlorine or ozone/chlorine combination [4]. However, virus is resistant to both UV and combined chlorine disinfection. The recent approach based on active photocatalysis by using $\mathrm{AuTiO}_{2}$ suspension and targeting bacteria and virus from water.

The use of solar irradiation for treatment of contaminated water is an age old technology [5]. The bacterial inactivation rate in contaminated water is proportional to intensity of sunlight, temperature and inversely proportional to water depth [6]. The rapid growth of nanotechnology has provided many types of material for water decontamination [6]. The antibacterial mechanism of $\mathrm{Ag}, \mathrm{TiO}_{2}, \mathrm{ZnO}[7,8]$ and metals like platinum [9], gold [10], silver [7], Zn [8] in nano form are known for their resonance under illumination. Metal doping has been used to enhance $\mathrm{TiO}_{2}$, photocatalysis by tapping excited electrons to prevent charge recombination as electron tapping can occur it the doping has a lower level than excited electrons [11]. Matsunga et al. first time reported photocatalytic inactivation of microorganisms. They inactivated Lactobacillus acidophilus, Saccharomyces servisiae and E. coli using $\mathrm{TiO}_{2}$ particle suspension [12]. Wei et al. used $\mathrm{P} 25\left(\mathrm{TiO}_{2}\right.$ Degussa) to inactivate E. coli in water [13]. Gold nanoparticle may become useful in the development of antimicrobial strategies because of their nontoxicity, versatility in surface modification polyvalent effect and photo thermal effect [14].

The comprehensive studies on gold nanomaterial have rarely been carried out in bacteria. To understand the interaction of doped $\mathrm{AuTiO}_{2}$ in presence of sunlight, investigation was carried out for antibacterial effects on model gram negative Escherichia coli and gram positive Streptococcus aureus.

\section{Materials and Methods}

\section{Preparation and characterization of nanoparticles}

Pre weighed quantity of $\mathrm{Au}$ and $\mathrm{TiO}_{2}(60 \mathrm{mg} \mathrm{Au}$ and $2960 \mathrm{mg}$ of $\mathrm{TiO}_{2}$ ) were loaded in a crucible and placed at the bottom of reactor. The reactor was evacuated in presence of liquid nitrogen and heated resistively to achieve condensation of $\mathrm{Au}$ atom with solvent molecules. After completion of reaction the reactor was brought to the room temperature under $\mathrm{Ar}$ atmosphere. On cooling $\mathrm{Au}$ solvent colloid comes in contact with $\mathrm{TiO}_{2}$, this mixture was stirred for $2 \mathrm{hrs}$ in $\mathrm{Ar}$ atmosphere, recovered and vacuum dried [15].

\section{Characterization of $\mathrm{AuTiO}_{2}$ nanoparticles}

The crystal structure of the nanoparticle was analyzed by X-ray diffraction (XRD) using a D/MAX-2004 X-ray powder diffractometer (Rigaku Corporation, Tokyo, Japan) with Cu target $(0.1540598 \mathrm{~nm})$ radiation at $40 \mathrm{kV}$ and $181 \mathrm{~mA}$. Scanning range was varied between $10^{\circ}$ and $90^{\circ}$ at a scanning rate of $2^{\circ} / \mathrm{min}$. The morphology of these nanoparticles was examined by both Field Emission Scanning Electron Microscopy (FESEM) and Energy Dispersive X-ray spectroscopy (EDAX). FESEM/EDAX (JEOL Ltd., Tokyo, Japan) samples were prepared by dispersing in a thin film of the photocatalyst on a grid that was operated at $15.0 \mathrm{KV}$. EDAX was performed to the ratio of the nanoparticles present.

*Corresponding author: Sandhya S, CSIR-National Environmental Engineering Research Institute, CSIR-Complex, Chennai, India, Tel: 044-255-419-64; E-mail: sswami_in@yahoo.com

Received July 14, 2014; Accepted September 18, 2014; Published September 24, 2014

Citation: Sandhya S, Rayalu S, Bruno B (2014) Solar Light Induced Photo Catalytic Disinfection of Gram Positive and Negative Microorganisms from Water with Highly Efficient AuTiO ${ }_{2}$ Nanoparticle. J Bioprocess Biotech 4: 176 doi: 10.4172/2155-9821.1000176

Copyright: (c) 2014 Sandhya S, et al. This is an open-access article distributed under the terms of the Creative Commons Attribution License, which permits unrestricted use, distribution, and reproduction in any medium, provided the original author and source are credited. 
Citation: Sandhya S, Rayalu S, Bruno B (2014) Solar Light Induced Photo Catalytic Disinfection of Gram Positive and Negative Microorganisms from Water with Highly Efficient $\mathrm{AuTiO}_{2}$ Nanoparticle. J Bioprocess Biotech 4: 176 doi: 10.4172/2155-9821.1000176

\section{Scanning electron microscopy}

SEM observation was made with a SEM LEO SUPRA 35 (Carl ZEISS Inc., Oberkochen, Germany) at an acceleration voltage of $20 \mathrm{kV}$. Before imaging, the sample was sputtered with gold for $90 \mathrm{~s}$ (Cressington Sputter Coater 208HR, Cressington Scientific Instrument Ltd., Watford, U.K.). The pellet was fixed in $2.5 \%$ glutaraldehyde for $2 \mathrm{~h}$ in a refrigerator and was washed with phosphate buffer and dehydrated with ethanol. Then these cells were placed on the grids which was sputtered with gold for 110s (Cressington Sputter Coater 208 HR, Cressington Scientific Instrument Ltd.) and the image was captured using the SEM LEO SUPRA 35.

\section{Determination of bactericidal activity}

E. coli and Staphylococcus aureus were used as a model bacterium to evaluate antibacterial activity of $\mathrm{AuTiO}_{2}$ nanoparticles prepared in the study. To evaluate the bactericidal effect of $\mathrm{AuTiO}_{2}$ nanoparticles, $E$. coli and $S$. aureus were first precultured in flasks containing nutrient broth at $37^{\circ} \mathrm{C}$ to a concentration of $10^{8} \mathrm{CFU} / \mathrm{ml} .1 \mathrm{ml}$ of the cell suspension was added in $99 \mathrm{ml}$ of sterile Phosphate Buffer Saline (PBS) to get $10^{5} \mathrm{CFU} / \mathrm{ml}$. Prepared $\mathrm{AuTiO}_{2}$ nanoparticles $(10 \mathrm{ug} / \mathrm{ml}$ and $20 \mathrm{ug} / \mathrm{ml}$ ) were added and exposed to direct sun light. The samples were collected at equal intervals and were plated on Mac Conkey agar plates to know the count of surviving E. coli and Nutrient agar for $S$. aureus. The dead cells were further subjected to SEM to know their morphological changes.

\section{Results}

\section{Characterization of $\mathrm{AuTiO}_{2}$}

XRD pattern of $\mathrm{AuTiO}_{2}$ nanocomposite synthesized is shown in figure 1 . The calcined samples were examined by powder XRD analysis and the spectra suggest high degree of crystallinity in each case. The Au peak can be indexed at $2^{\circ}$ value $38.2,48,64.7$ peaks. This clearly indicates that the structural integrity of titanium has been retained.

The SEM micrograph of the prepared catalytic material was obtained to investigate the powder morphology and microstructures of the $\mathrm{AuTiO}_{2}$ (Figure 2). The particle size of the developed material in the photograph shows a homogenous distribution of the crystalline material although not fully resolved. The image highly dispersed nanoparticles in the system. EDAX spectra Figures $2 \mathrm{~B}$ and 2C confirms the presence of Ti with $\mathrm{ka}$ line at $4.5 \mathrm{keV}, \mathrm{V}$ with $\mathrm{La}$ line at $0.5 \mathrm{keV}$ and Au with La line $2.1 \mathrm{kev}$.

\section{Effects of cell and $\mathrm{AuTiO}_{2}$ concentrations on disinfection}

The nanoparticle was successfully tested for artificially contaminated water with E. coli and S. aureus. The average irradiation intensity ranged from $500-888 \mathrm{Wm}^{-2}$ with exposure up to $120 \mathrm{~min}$. The final temperature during the exposure was always more than $36^{\circ} \mathrm{C}$. Bacterial concentrations in the treated samples were determined by plating. E. coli and S. aureus cells were exposed to $\mathrm{AuTiO}_{2}$ for $2 \mathrm{hrs}$ in solar light to assess any bactericidal effect of the photocatalyst. At higher initial cell concentrations, the colony count decreased with time as shown in figure $\left.3 \mathrm{~A}(10 \mathrm{ug} / \mathrm{ml} \mathrm{AuTiO})_{2}\right)$ and $\mathrm{B}\left(20 \mathrm{ug} / \mathrm{ml} \mathrm{AuTiO}{ }_{2}\right)$ for $E$. coli and figure 4 for $S$. aureus respectively. A typical death curve was observed for bacteria in solar light over time, thus it appeared that dyeing effect of the light irradiation was causing decrease in cell viability. Within the first 15 mins of irradiation in solar light, $91.7 \%$ $95.7 \%$ of E. coli and $87.7 \%-96.9 \%$ of $S$. aureus were viable, while the number of viable bacteria decrease progressively on further exposure.

In order to study the disinfection mechanism, a high concentration of cells is required to expose the nanomaterial resulting from $\mathrm{AuTiO}_{2}$

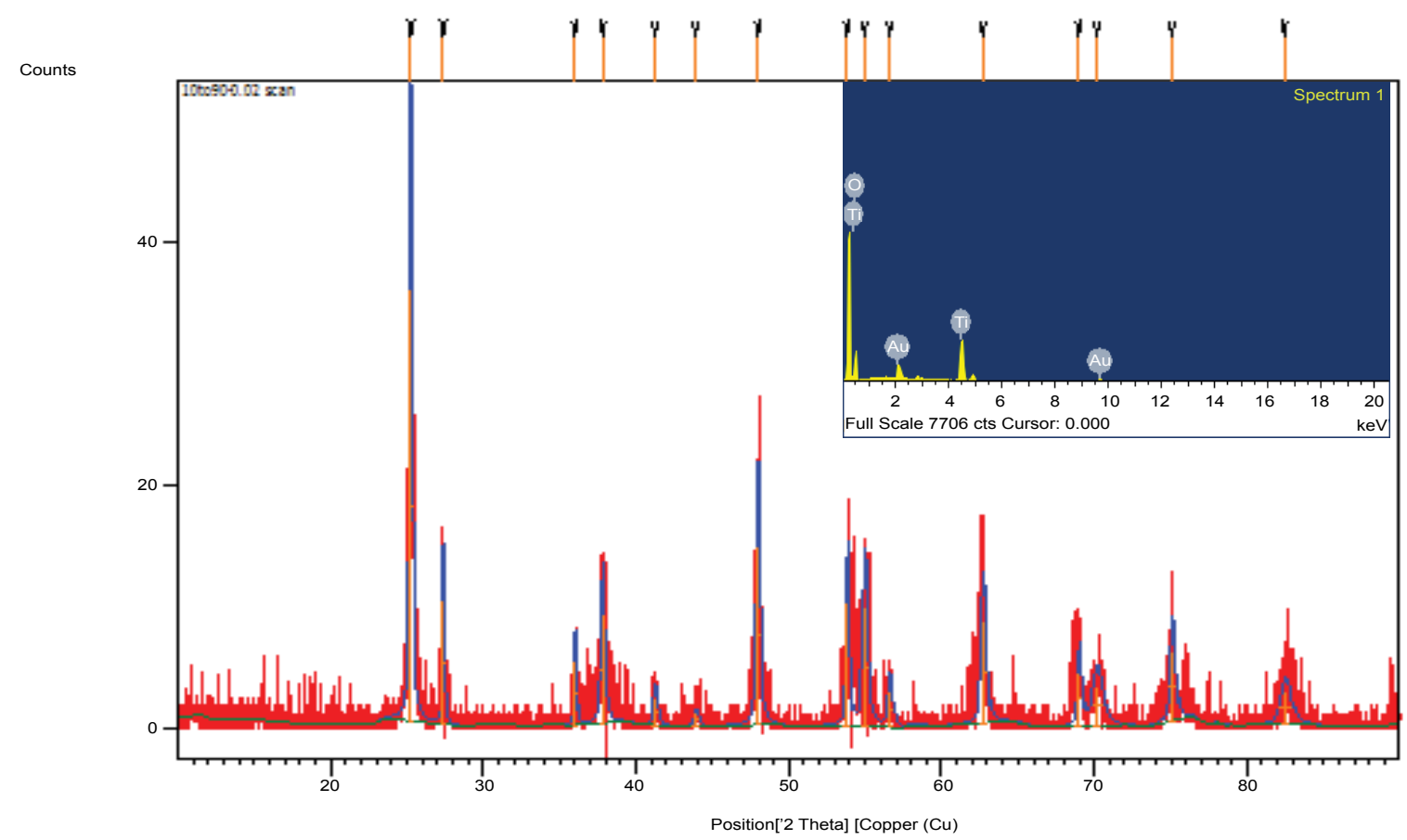

Figure 1: XRD Pattern of the $\mathrm{AuTiO}_{2}$ nanoparticle 
Citation: Sandhya S, Rayalu S, Bruno B (2014) Solar Light Induced Photo Catalytic Disinfection of Gram Positive and Negative Microorganisms from Water with Highly Efficient $\mathrm{AuTiO}_{2}$ Nanoparticle. J Bioprocess Biotech 4: 176 doi: 10.4172/2155-9821.1000176

Page 3 of 6

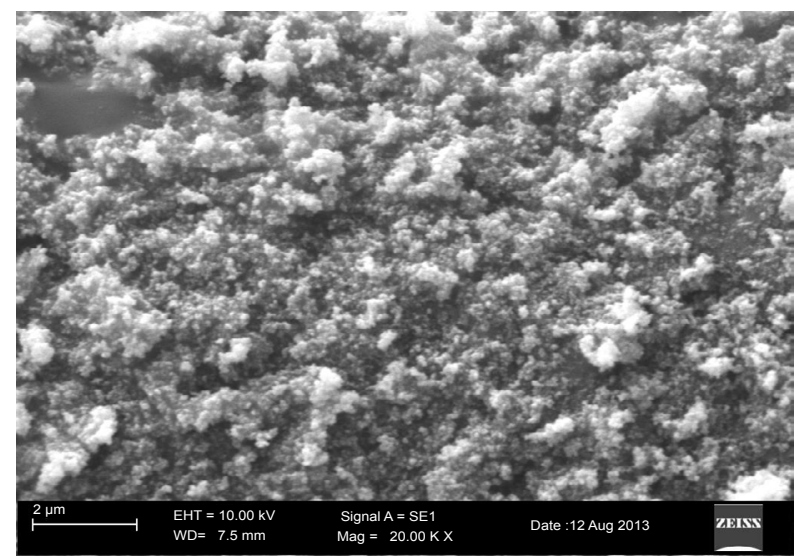

Figure 2: EDAX and FEMS image explaining the morphology of the AuTiO, nanoparticle.

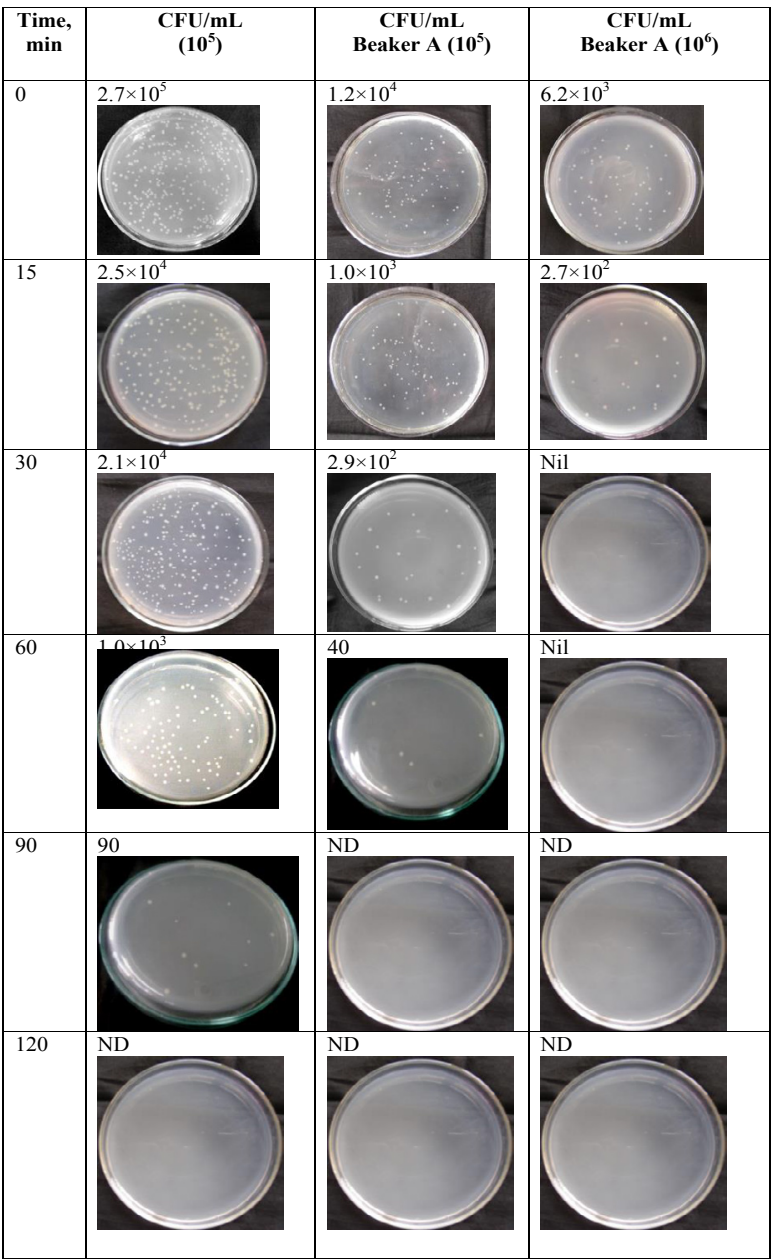

Figure 3A: E.coli disinfection in presence of $\mathrm{AuTiO}_{2}(10 \mathrm{ug} / \mathrm{ml})$.

biocidal action. To determine the optimal dose of $\mathrm{AuTiO}_{2}$ for a certain cell concentration, a solar photocatalytic reaction were carried out with the cell concentration raging from $6.6 \times 10^{3}$ to $2.8 \times 10^{5} \mathrm{CFU} / \mathrm{ml}$ and $\mathrm{AuTiO}_{2}$ concentrations ranging from 10 to $20 \mathrm{ug} / \mathrm{ml}$ (Table 1

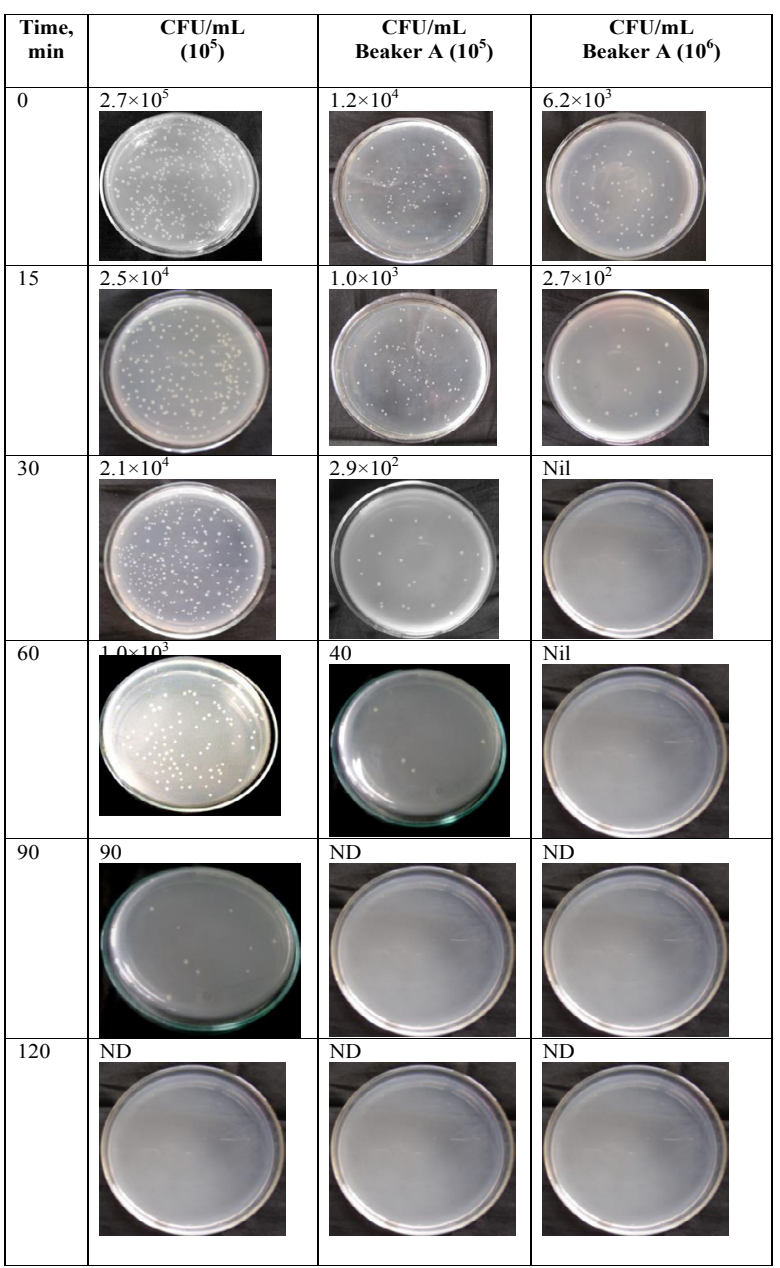

Figure 3B: E.coli disinfection in presence of $\mathrm{AuTiO}_{2}(20 \mathrm{ug} / \mathrm{ml})$.

and Figure 5). After $60 \mathrm{~min}$ of irradiation in solar light in presence of $\mathrm{AuTiO}_{2} 10 \mathrm{ug} / \mathrm{ml}, 97.8$ to $99.2 \%$ of $E$. coli was killed, when the initial cell concentration was less than $10^{5} \mathrm{CFU} / \mathrm{ml}$. When the $\mathrm{AuTiO}_{2}$ dose was increased to $20 \mathrm{ug} / \mathrm{ml}$, the disinfection or killing rate was 99.6 to $99.99 \%$. This shows significant improvement in the disinfection efficiency at higher dose. Therefore the most effective $\mathrm{AuTiO}_{2}$ concentration for disinfection of $E$. coli was $20 \mathrm{ug} / \mathrm{ml}$ at initial cell concentration ranging from $10^{3}$ to $10^{5} \mathrm{CFU} / \mathrm{ml}$. The same concentration of $\mathrm{AuTiO}_{2}(20 \mathrm{ug} /$ $\mathrm{ml}$ ) when tested against gram positive S.aureus showed 99.5 to 99.99 disinfection efficiency.

Results of photocatalytic inactivation of E. coli and S. aureus using $\mathrm{AuTiO}_{2}$ are shown in figures 6 and 7 respectively. The figures suggest that bacterial growth were less inhibited in presence of 0 and $10 \mathrm{ug} / \mathrm{ml}$ of $\mathrm{AuTiO}_{2}$. It was observed that bacteria were inhibited by only $\mathrm{TiO}_{2}$ particles as it generates $\mathrm{OH}$ radical (Data not shown). On the other hand, gold has low toxicity to biological systems or animals or human, due to elemental properties [14]. In both the cases, the concentration of bacteria seems to exponentially decrease with respect to inactivation time. This indicates that inactivation of both the bacteria follows Chick's Law, which says that the inactivation rate of bacteria can be expressed as a first ordered reaction with respect to the concentration of viable cell. According to Chick's Law the inactivation can be given as follows, 
Citation: Sandhya S, Rayalu S, Bruno B (2014) Solar Light Induced Photo Catalytic Disinfection of Gram Positive and Negative Microorganisms from Water with Highly Efficient $\mathrm{AuTiO}_{2}$ Nanoparticle. J Bioprocess Biotech 4: 176 doi: 10.4172/2155-9821.1000176

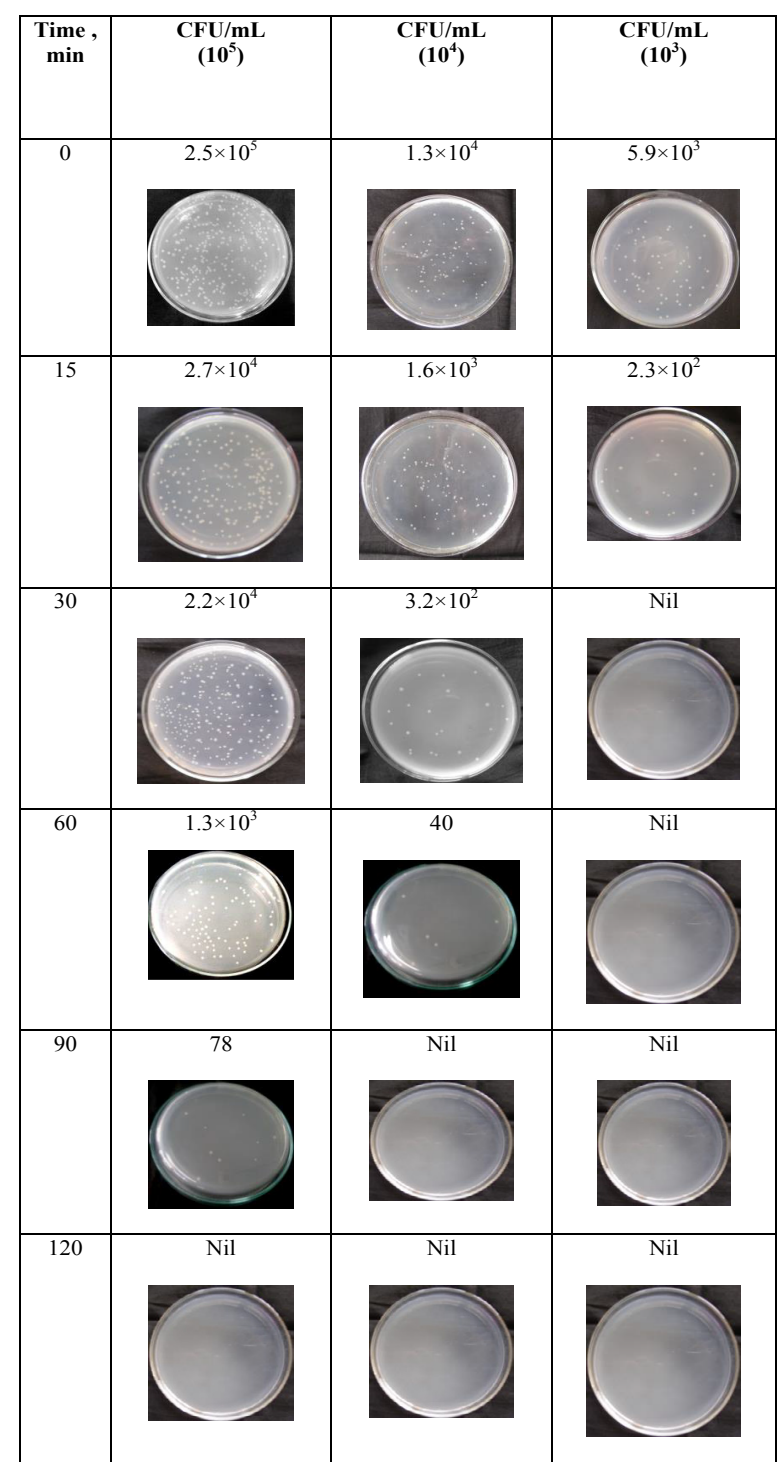

Figure 4: Staphylococci aureus disinfection in presence of $\mathrm{AuTiO}_{2}(20 \mathrm{ug} / \mathrm{ml})$.

\begin{tabular}{|c|c|c|c|c|c|}
\hline Microorganisms & $\begin{array}{l}\text { Cell conc., } \\
\text { CFU/ml }\end{array}$ & $\begin{array}{l}\mathrm{AuTiO}_{2} \\
10 \mathrm{ug} / \mathrm{I}\end{array}$ & $\begin{array}{l}\text { Survival } \\
\text { ratio, \%" }\end{array}$ & $\begin{array}{c}\text { AuTiO }_{2} \\
20 \mathrm{ug} / \mathrm{ml}\end{array}$ & $\begin{array}{l}\text { Survival } \\
\text { ratio, \%* }\end{array}$ \\
\hline \multirow{6}{*}{ E.coli } & $2.8 \times 10^{5}$ & $2.3 \times 10^{3}$ & 0.82 & - & - \\
\hline & $1.0 \times 10^{4}$ & $2.2 \times 10^{2}$ & 2.2 & - & - \\
\hline & $6.6 \times 10^{3}$ & 45 & 0.68 & - & - \\
\hline & $2.7 \times 10^{5}$ & - & - & $1.1 \times 10^{3}$ & 0.40 \\
\hline & $1.2 \times 10^{4}$ & - & - & 90 & 0.75 \\
\hline & $6.2 \times 10^{3}$ & - & - & ND & 0.016 \\
\hline \multirow{3}{*}{ S.aureus } & $2.5 \times 10^{5}$ & - & - & $1.3 \times 10^{3}$ & 0.52 \\
\hline & $1.3 \times 10^{4}$ & - & - & 40 & 0.31 \\
\hline & $5.9 \times 10^{3}$ & - & - & ND & 0.017 \\
\hline
\end{tabular}

ND: Not Detected

${ }^{*}$ Ratio of cell concentration after 60 min in solar light to the corresponding initial concentration

Table 1: Effect of Escherichia coli, Staphylococcus aureus and $\mathrm{AuTiO}_{2}$ concentrations on its disinfection.

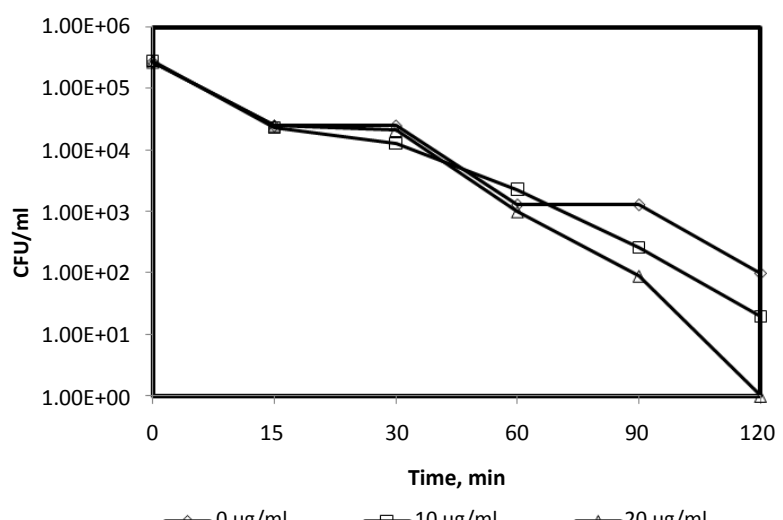

Figure 5: Survival ratio of E.coli with $\mathrm{AuTiO}_{2}$ photocatlyst at different concentrations samples exposed to solar light.

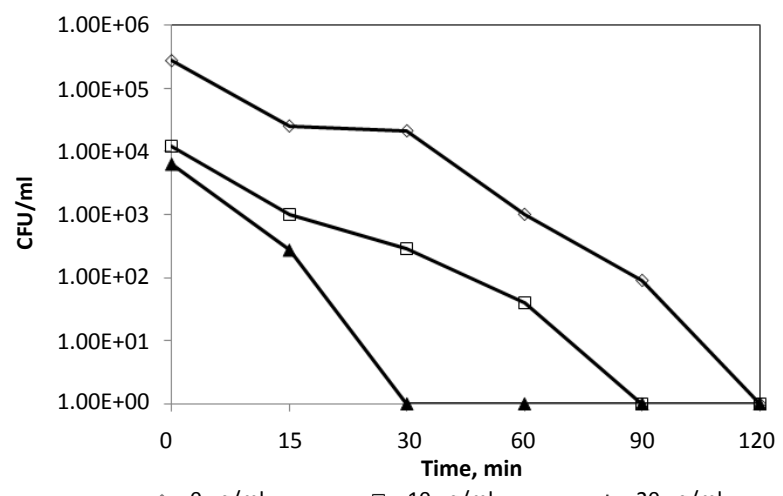

Figure 6: Survival ratio of E.coli at various concentration of $\mathrm{AuTiO}_{2}$.

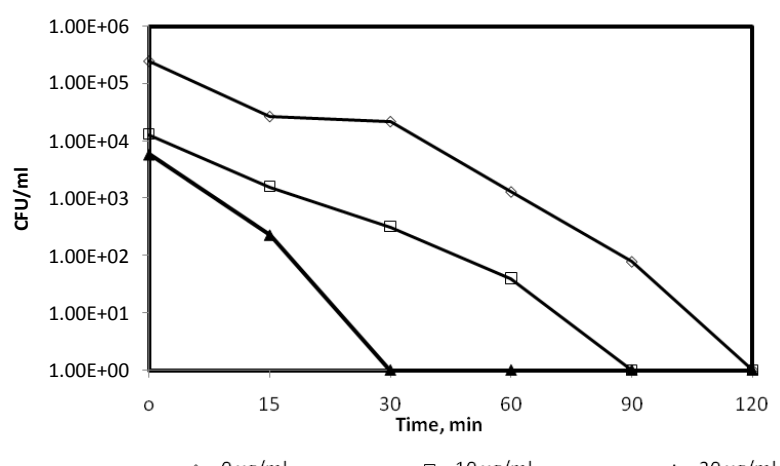

Figure 7: Survival ratio of $S$. aureus at various concentration $\mathrm{AuTiO}_{2}$.

$$
-k c t=\frac{d c t}{d t}
$$

Where, $\mathrm{ct}$ is the active cell concentration at time $\mathrm{t}$, From the equation the inactivation rate constant can be obtained as

$$
k=\frac{\ln \frac{C t}{C o}}{T}
$$


Citation: Sandhya S, Rayalu S, Bruno B (2014) Solar Light Induced Photo Catalytic Disinfection of Gram Positive and Negative Microorganisms from Water with Highly Efficient $\mathrm{AuTiO}_{2}$ Nanoparticle. J Bioprocess Biotech 4: 176 doi: 10.4172/2155-9821.1000176

Since the initial concentration was fixed as $10^{5} \mathrm{cells} / \mathrm{ml}$, the inactivation rate constant can represent the inactivation efficiency of photocatalyst. The $\mathrm{k}$ value for each concentration was obtained liner slop of a log scale plot of photocatalyst. The activation rate constant $\mathrm{k}$ for each case is given in table 2. Values of $\mathrm{k}$ show comparable disinfection with that of Herrera Melian et al. They required 120 min for two log inactivation of total coliforms [16]. In every experiment sample temperature was always monitored and values are higher than $36^{\circ} \mathrm{C}$ and therefore disinfection caused by temperature was minimum. Evidence of SEM image (Figure 8) showed that the $\mathrm{AuTiO}_{2}$ nanoparticles could adhere to the outer cell of bacteria in a dark media. Though the outer membrane of the cell was not damaged, the bacteria cannot nourish from aqueous media.

\section{Proposed mechanism of photocatalytic disinfection of microorganisms using AuTiO2 nanoparticles}

The role of complex photo oxidants, such as hydroxyl radical $(\mathrm{OH})$ the superoxide radical $\left(\mathrm{O}_{2}\right)$ and hydrogen peroxide $\left(\mathrm{H}_{2} \mathrm{O}_{2}\right)$ etc still not fully understood. Figure 9 reports the probable disinfection mechanism using nanomaterial $\mathrm{AuTiO}_{2}$. It is frequently assumed that the hydroxyl radical is a major factor responsible for the antimicrobial activity observed in $\mathrm{AuTiO}_{2}$ photocatalytical reaction [17]. On the other hands Maners et al. reported that other Reactive Oxygen Species (ROS) $\left(\mathrm{H}_{2} \mathrm{O}_{2}\right.$ and $\mathrm{O}_{2}^{-}$etc) as well as the hydroxyl radical play significant role in microorganism's inactivation [17]. The gold nanoparticles exert their antibacterial action mainly inhibiting ATP synthesis with decline in metabolism or inhibit subunit of ribosome from the rRNA binding [10].

\section{Discussion}

The result on viability study confirmed the previous finding of Cui et al. [10] and Zhou et al.[14] that $\mathrm{AuTiO}_{2}$ in solar light exhibits bactericidal activity and that the disinfection is positively correlated with the $\mathrm{AuTiO}_{2}$ dose $(20 \mathrm{ug} / \mathrm{ml})$. The survival ration in table 1

\begin{tabular}{|c|c|c|c|}
\hline \multirow{2}{*}{ Bacteria } & \multicolumn{3}{|c|}{ AuTiO $_{\mathbf{2}} \mathbf{~} / \mathbf{m i n}$} \\
\cline { 2 - 4 } & $\mathbf{0 ~} \mathbf{~ u g} / \mathbf{m l}$ & $\mathbf{1 0} \mathbf{~} \mathbf{g} / \mathbf{m l}$ & $\mathbf{2 0} \mathbf{~} \mathbf{g} / \mathbf{m l}$ \\
\hline Escherichia coli & 0.082 & 0.049 & 0.042 \\
\hline Staphylococcus aureus & 0.054 & 0.051 & 0.041 \\
\hline
\end{tabular}

Table 2: Inactivation rate constant of photocatalytic inactivation of Escherichia coli, Staphylococcus aureus in solar irradiation.

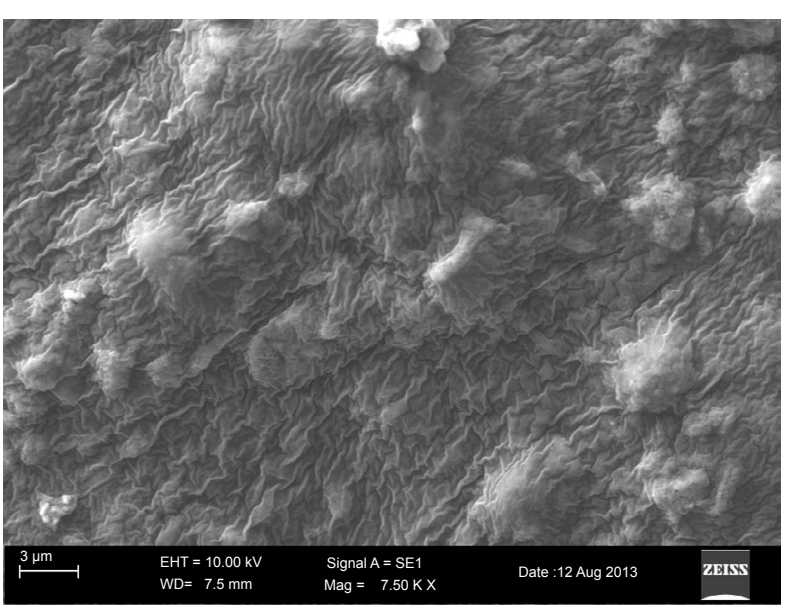

Figure 8: SEM image of the bacterial cells after treatment with $\mathrm{AuTiO}_{2}$ nanoparticle in solar light.

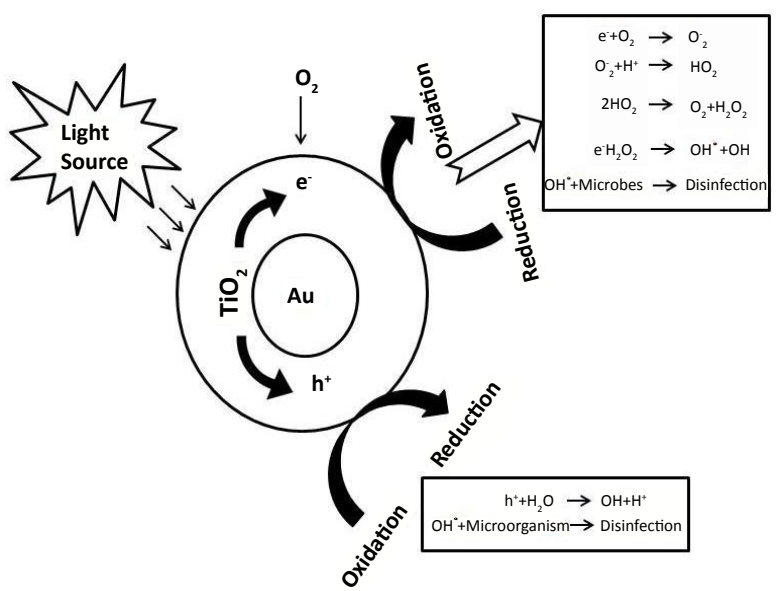

Figure 9: Proposed mechanism of photocatalytic disinfection of microorganisms using $\mathrm{AuTiO}_{2}$ nanoparticles.

compared the levels of viability at different dose of $\mathrm{AuTiO}_{2}$ in solar light. Experiments were conducted using E. coil DH5a and S. aureus and selective media was used for bacterial detection during photo treatment. This point is of great importance when the purpose of treatment is to get portable water.

The inactivation effect of light in presence of photocatalyst depends on the original bacterial growth state. Always sixteen hours grown cells were used in the study. The deactivation rate increases with decrease in initial concentrations of bacteria. The deactivation rate constant was lower for E. coli and S. aureus in presence of $\mathrm{AuTiO}_{2}(20 \mathrm{ug} / \mathrm{ml})$ than in absence of the same.

Based on photocatalytic disinfection mechanism of nanomaterial $\left(\mathrm{AuTiO}_{2}\right)$ the ROS such as $\mathrm{OH}^{-}, \mathrm{O}_{2}^{-}$and $\mathrm{H}_{2} \mathrm{O}_{2}$ generated on the irradiated $\mathrm{AuTiO}_{2}$ surface, attack either ATP synthesis or the rRNA binding in bacteria. The disinfection mechanism reported here may be outside the cell is very likely the initial mode of killing. However, we cannot rule out the possibility of photocatalytic attack inside the bacterial cells.

\section{Acknowledgement}

Authors are thankful to Ms Sumana Biswas for some study. Authors are thankful to Director, NEERI, Nagpur, India and the CSIR- SIP for funding the project.

\section{References}

1. Caslake LF, Connolly DJ, Menon V, Duncanson CM, Rojas R, et al. (2004) Disinfection of contaminated water by using solar irradiation. Appl Environ Microbiol 70: 1145-1150

2. Weber WJ Jr (2002) Distributed optimal technology networks: a concept and strategy for potable water sustainability. Water Sci Technol 46: 241-246.

3. Szewzyk U, Szewzyk R, Manz W, Schleifer KH (2000) Microbiological safety of drinking water. Annu Rev Microbiol 54: 81-127.

4. Zhang D, Li G, Yu JC (2010) Inorganic material for photocatalytic water disinfection.J Mater Chem 20: 4529-4536.

5. Acra A, Jurdi M, Muállem H, Karahagopian Y, Raffoul Z (1996) Water disinfection by solar irradiation:Assessment\& Application.Intemational Development Research Centre, Canada.

6. Yacoby I, Benhar I (2008) Antibacterial nanomedicine. Nanomedicine (Lond) 3: 329-341.

7. Li Q, Mahendra S, Lyon DY, Brunet L, Liga MV, et al. (2008) Antimicrobial 
Citation: Sandhya S, Rayalu S, Bruno B (2014) Solar Light Induced Photo Catalytic Disinfection of Gram Positive and Negative Microorganisms from Water with Highly Efficient AuTiO ${ }_{2}$ Nanoparticle. J Bioprocess Biotech 4: 176 doi: 10.4172/2155-9821.1000176

nanomaterials for water disinfection and microbial control: potential applications and implications. Water Res 42: 4591-4602.

8. Huang Z, Zheng X, Yan D, Yin G, Liao X, et al. (2008) Toxicological effect of $\mathrm{ZnO}$ nanoparticles based on bacteria. Langmuir 24: 4140-4144.

9. Ahmadi TS, Wang ZL, Green TC, Henglein A, El-Sayed MA (1996) ShapeControlled Synthesis of Colloidal Platinum Nanoparticles Science 272: 19241926.

10. Cui Y, Zhao Y, Tian Y, Zhang W, Lü X, et al. (2012) The molecular mechanism of action of bactericidal gold nanoparticles on Escherichia coli. Biomaterials 33: $2327-2333$

11. Iliev V, TomovaD, BilyarskaL, Eliyas A, Petrov L(2006) Photocatalytic properties of $\mathrm{TiO}_{2}$ modified with platinum and silver nanoparticles in the degradation of oxalic acid in aqueous solution.Applied Catalysis B: Environmental 63: 266-271.

12. Matsunga T, Tomoda R, Nakajima T, Wake H (1985) Photoelectrochemical sterilization of microbial cells by semiconductor powders.FEMS Microbiology Letters 29: 211-214.
13. Wei C, Lin WY, Zainal Z, Williams NE, Zhu K, et al. (1994) Bactericidal Activity of $\mathrm{TiO}_{2}$ Photocatalyst in Aqueous Media: Toward a Solar-Assisted Water Disinfection System. Environ Sci Technol 28: 934-938.

14. Zhou Y, Kong Y, Kundu S, Cirillo JD, Liang H (2012) Antibacterial activities of gold and silver nanoparticles against Escherichia coli and bacillus CalmetteGuérin. J Nanobiotechnology 10: 19.

15. Rayalu SS, Jose D, Joshi MV, Mangrulkar PA, Shrestha K, et al. (2013) Photocatalytic water splitting on $\mathrm{Au} / \mathrm{TiO}_{2}$ nanocomposites synthesized through various routes: Enhancement in photocatalytic activity due to SPR effect. Applied Catalysis B: Environmental 142-143: 684-693.

16. Herrera Melián JA, Doña Rodríguez JM, VieraSuárez A, TelloRendón E, Valdés do Campo C, et al. (2000) The photocatalytic disinfection of urban waste waters. Chemosphere 41: 323-327.

17. Maness PC, Smolinski S, Blake DM, Huang Z, Wolfrum EJ, et al. (1999) Bactericidal activity of photocatalytic $\mathrm{TiO}(2)$ reaction: toward an understanding of its killing mechanism. Appl Environ Microbiol 65: 4094-4098. 